\title{
Many ways to displace a blood clot. But do we need to do so?
}

\author{
J. C. van Meurs ${ }^{1}$
}

Received: 7 November 2019 / Accepted: 7 November 2019 / Published online: 10 December 2019

(c) The Royal College of Ophthalmologists 2019

In this issue Erdogan et al. [1] describe an original approach to submacular haemorrhage (SMH) displacement. They simply create a subretinal fluid area bathing the submacular blood clot in tissue plasminogen activator (TPA), without the use of any gas. This report illustrates the continuing interest in the best way to deal with SMHs and at the same time highlights the lack of solid data on its management.

$\mathrm{SMH}$ is most commonly encountered as an infrequent, but severe complication of choroidal neovascularization in the course of exudative age-related macular degeneration (AMD).

The treatment of exudative AMD has been revolutionised by the introduction of anti-VEGFs from 2006 onwards [2]. Although almost all studies have excluded patients with SMHs, sporadic case series have shown acceptable results in the presence of substantial (up to $600 \mu \mathrm{m}$ thickness) SMH [3-7]. Also, the prospective CATT study included some patients with smaller SMHs [8].

Nevertheless, such reports are heavily outnumbered by a large body of case series $[9,10]$ and one pilot prospective comparative trial [11] that study efforts to displace SMH.

This concept of the necessity of displacing SMH is based on experimental studies in different animal species, where blood was found to be rapidly toxic to the overlying retina $[12,13]$. Factors specified include iron toxicity, fibrin contraction and interference with metabolic support from the choroid by a diffusion barrier to the retina.

To address fibrin contraction and adherence to the surrounding tissues and to induce liquefaction of the clotted haemorrhage, TPA has been studied and applied from early on [14].

\section{J. C. van Meurs}

j.vanmeurs@oogziekenhuis.nl

1 Rotterdam Eye Hospital and Erasmus University, Rotterdam, The Netherlands
Clinical efforts of haemorrhage removal started with forceps removal through a paramacular retinotomy, sometimes aided by prior rinsing with TPA, or application of TPA and the creation of a more peripheral retinomy to drain the liquefied clot $[15,16]$.

In 1996, at the Vail Vitrectomy Meeting, Wilson Heriot introduced pneumatic displacement, showing that intravitreally injected gas and TPA could effectively displace an $\mathrm{SMH}$. This approach has been modified and embellished in many ways: with vitrectomy and a vitreous cavity filled with short or long action gas or with air, with gas bubbles under the retina [17] or not, with TPA in the vitreous or under the retina or no TPA at all. All more recent reports sensibly incorporated anti-VEGF treatment to prevent or slow down progression of the underlying choroidal neovascularization.

In these reports, the different choices of displacement appeared to be of comparable effectivity [9], and the only randomised controlled trial (RCT) showed no difference between the two tested displacement methods (subretinal TPA, vitrectomy and gas versus injection of intravitreal TPA and gas only) [11].

Uncertain in these methods is the mechanism of its operation. Is it a steamer roller-like action of the gas bubble, which displaces the haemorrhage from the macula or the effect of gravity when most of the denser haemorrhage is surrounded by air or gas [18]?

Erdogan's study specifically identifies another quiet indisputable mechanism, i.e. the small force of gravity in surrounding fluid, as demonstrated daily in the timehonoured erythrocyte sedimentation rate test: cells are slightly more dense than serum.

If one were to run an RCT to sort out which displacement method were the best, we would end up with a study of 72 arms: not a realistic effort.

The bottom line, however, remains that surgeons should first prove that displacement is better than no displacement. The lack of such proof may be one of the causes that not all patients with an acute SMH are swiftly referred for displacement surgery [19]. 
For that reason, Euretina is funding an RCT where one consensus displacement method is compared with aflibercept injections only. Of interest, the displacement method chosen (vitrectomy, subretinal TPA, intravitreal aflibercept and gas) fortunately also incorporates the mechanism that Erdogan's study has highlighted.

This study, led by Tim Jackson (King's College London), will hopefully teach us whether our surgical enthusiasm is really helpful for the patient with an acute SMH or that our patients would benefit most from the safer antiVEGF injections alone.

\section{Compliance with ethical standards}

Conflict of interest The author declares no conflict of interest.

Publisher's note Springer Nature remains neutral with regard to jurisdictional claims in published maps and institutional affiliations.

\section{References}

1. Erdogan G, Kirmaci A, Perente I, Artunay O. Gravitational displacement of submacular haemorrhage in patients with age-related macular disease. Eye (London, England) 2019.

2. Rosenfeld PJ, Rich RM, Lalwani GA. Ranibizumab: phase III clinical trial results. Ophthalmol Clin North Am. 2006;19:361-72.

3. Kim JH, Chang YS, Kim JW, Kim CG, Yoo SJ, Cho HJ. Intravitreal anti-vascular endothelial growth factor for submacular hemorrhage from choroidal neovascularization. Ophthalmology. 2014;121:926-35.

4. Cho HJ, Koh KM, Kim HS, Lee TG, Kim CG, Kim JW. Antivascular endothelial growth factor monotherapy in the treatment of submacular hemorrhage secondary to polypoidal choroidal vasculopathy. Am J Ophthalmol. 2013;156:524-31.e521.

5. Stifter E, Michels S, Prager F, Georgopoulos M, Polak K, Hirn C, et al. Intravitreal bevacizumab therapy for neovascular age-related macular degeneration with large submacular hemorrhage. Am J Ophthalmol. 2007;144:886-92.

6. Shienbaum G, Garcia Filho CA, Flynn HW Jr, Nunes RP, Smiddy WE, Rosenfeld PJ. Management of submacular hemorrhage secondary to neovascular age-related macular degeneration with antivascular endothelial growth factor monotherapy. Am J Ophthalmol. 2013;155:1009-13.
7. Chang MA, Do DV, Bressler SB, Cassard SD, Gower EW, Bressler NM. Prospective one-year study of ranibizumab for predominantly hemorrhagic choroidal neovascular lesions in agerelated macular degeneration. Retina. 2010;30:1171-6.

8. Altaweel MM, Daniel E, Martin DF, Mittra RA, Grunwald JE, Lai MM, et al. Outcomes of eyes with lesions composed of $>50 \%$ blood in the Comparison of Age-related Macular Degeneration Treatments Trials (CATT). Ophthalmology. 2015;122: $391-5$.

9. van Zeeburg EJ, Van Meurs JC. Literature review of recombinant tissue plasminogen activator used for recent-onset submacular hemorrhage displacement in age-related macular degeneration. Ophthalmologica. 2013;229:1-14.

10. Stanescu-Segall D, Balta F, Jackson TL. Submacular hemorrhage in neovascular age-related macular degeneration: a synthesis of the literature. Surv Ophthalmol. 2016;61:18-32.

11. de Jong JH, van Zeeburg EJ, Cereda MG, van Velthoven ME, Faridpooya K, Vermeer KA, et al. Intravitreal versus subretinal administration of recombinant tissue plasminogen activator combined with gas for acute submacular hemorrhages due to agerelated macular degeneration: an exploratory prospective study. Retina. 2016;36:914-25.

12. Hochman MA, Seery CM, Zarbin MA. Pathophysiology and management of subretinal hemorrhage. Surv Ophthalmol. 1997;42: 195-213.

13. Toth CA, Morse LS, Hjelmeland LM, Landers MB 3rd. Fibrin directs early retinal damage after experimental subretinal hemorrhage. Arch Ophthalmol. 1991;109:723-9.

14. Benner JD, Hay A, Landers MB 3rd, Hjelmeland LM, Morse LS. Fibrinolytic-assisted removal of experimental subretinal hemorrhage within seven days reduces outer retinal degeneration. Ophthalmology. 1994;101:672-81.

15. Lewis $\mathrm{H}$. Intraoperative fibrinolysis of submacular hemorrhage with tissue plasminogen activator and surgical drainage. Am J Ophthalmol. 1994;118:559-68.

16. Bressler NM, Bressler SB, Childs AL, Haller JA, Hawkins BS, Lewis $\mathrm{H}$, et al. Surgery for hemorrhagic choroidal neovascular lesions of age-related macular degeneration: ophthalmic findings: SST report no. 13. Ophthalmology. 2004;111:1993-2006.

17. Kim LA, Eliott D. Management of submacular hemorrhage in agerelated macular degeneration. Ophthalmol Retin. 2018;2:177-9.

18. Stopa M, Lincoff A, Lincoff H. Analysis of forces acting upon submacular hemorrhage in pneumatic displacement. Retina. 2007;27:370-4.

19. Al-Hity A, Steel DH, Yorston D, Gilmour D, Koshy Z, Young D, et al. Incidence of submacular haemorrhage (SMH) in Scotland: a Scottish Ophthalmic Surveillance Unit (SOSU) study. Eye. 2019; 33:486-91. 